\title{
KOMPETENSI GURU DALAM PENYUSUNAN INSTRUMEN IPS DI SDIT AL-FITYAN KECAMATAN SOMBA OPU KABUPATEN GOWA
}

\author{
Junaedi $^{1^{*}}$ \\ Aliem Bahri ${ }^{2}$ \\ Mirnawati ${ }^{2}$ \\ ${ }^{1}$ MIS Madani Alauddin Pao-Pao, Gowa, Indonesia \\ ${ }^{2}$ Universitas Muhammadiyah Makassar, Makassar, Indonesia \\ ${ }^{3}$ Yayasan Smart Home SD Islam Impian, Makassar, Indonesia
}

\begin{abstract}
Abstrak
Penelitian ini dilatarbelakangi oleh kenyataan bahwa kompetensi guru merupakan aspek yang sangat penting untuk peningkatan mutu pendidikan. Upaya meningkatkan mutu bidang pendidikan dapat dilakukan dengan cara berinovasi yang terintegrasi secara berkesinambungan. Tujuan penelitian ini yaitu untuk mendeskripsikan kemampuan guru, mengetahui faktor pendukung dan penghambat kompetensi guru dalam penyusunan instrumen penilaian mata pelajaran IPS di SDIT Al-fityan Kecamatan Somba Opu Kabupaten Gowa. Jenis penelitian yang digunakan adalah penelitian kualitatif melalui pendekatan deskriptif, dengan penentuan informan secara purposive sampling yang terdiri dari kepala sekolah, guru kelas III dan VI, serta peserta didik kelas III dan VI. Hasil penelitian ini menyimpulkan bahwa kompetensi guru yang mengajar di SDIT Al-Fityan Gowa sudah memiliki kompetensi pedagogik yang baik dalam penyusunan instrumen penilaian. Selain itu, peningkatan kompetensi pedagogik ditunjang dengan adanya faktor pendukung kompetensi guru yaitu: 1) Tingkat pendidikan yang tinggi. 2) Keikutsertaan dalam berbagai pelatihan dan kegiatan ilmiah. 3) Masa kerja dan pengalaman kerja. 4) Tingkat kesejahteraan. 5) Kesadaran kewajiban dan tanggung jawab. 6) Ketersediaan sarana dan prasarana. 7) Kepemimpinan kepala sekolah. 8) kegiatan pembinaan yang dilakukan. Faktor penghambat kompetensi pedagogik guru adalah kurangnya pemahaman tentang penilaian pada kurikulum 2013. Hasil penelitian ini diharapkan dapat dijadikan sebagai rujukan untuk upaya peningkatan kompetensi guru di abad 21.
\end{abstract}

Kata Kunci: Mutu Pendidikan, Kompetensi Guru, Pedagogik

\section{Pendahuluan}

Peranan guru Sekolah Dasar (SD) sebagai guru kelas harus menguasai seluruh mata pelajaran di SD. Begitu pula salah satu mata pelajaran khususnya mata pelajaran Ilmu Pengetahuan Sosial (IPS) tentu dapat dikuasai oleh guru. Jarolimek (2003) menyatakan "Social studies focuses specifically on citizenship education which means learning to participate in group life”. Dengan memahami tujuan pembelajaran IPS di SD, guru dapat melaksanakan pembelajaran IPS di SD secara terarah. Apabila seorang guru telah memiliki pemahaman yang mumpuni, maka bukan suatu hal yang sulit untuk menyusun perencanaan, pelaksanaan, dan 
penilaian pembelajaran. Berdasarkan pernyataan tersebut dapat disimpulkan bahwa IPS berperan dalam kelompok kehidupan. Menurut Depdiknas (2003) "Ilmu Pengetahuan Sosial di sekolah dasar mengkaji seperangkat peristiwa, fakta, konsep, generalisasi yang berkaitan dengan isu sosial serta berfungsi untuk mengembangkan pengetahuan, nilai, sikap, dan keterampilan siswa tentang masyarakat, bangsa, dan Negara”.

Penilaian pembelajaran merupakan seperangkat proses pengolahan informasi dalam rangka menentukan pencapaian hasil belajar. lebih lanjut Widaningsih (2011) mengemukakan "Evaluasi proses pembelajaran dilakukan untuk menentukan kualitas pembelajaran secara keseluruhan, mencakup tahap perencanaan, proses pelaksanaan, dan penilaian hasil pembelajaran". Dapat disimpulkan bahwa rangkaian proses penilaian pembelajaran terdapat pada perencanaan, pelaksanaan, pengolahan penilaian. Suatu keharusan bagi guru untuk mempersiapkan penilaian pembelajaran sejak penyusunan perencanaan pembelajaran berupa instrumen penilaian yang sesuai dengan prinsip dan prosedur penilaian. Berdasarkan hasil Uji Kompetensi Awal (UKA) guru yang dilaksanakan secara nasional pada tahun 2012 untuk hasil UKA guru SD memperoleh nilai rata-rata 36,86 dari skala nilai 100. Unifah Rosyidi selaku Kepala Pusat Pengembangan Profesi Pendidik Badan Pengembangan Sumber Daya Pendidikan dan Kebudayaan dan Penjaminan Mutu Pendidikan Kemendikbud mengatakan bahwa "selama ini guru dibina tanpa arah dan dasar. Akibatnya, pendidikan dan pelatihan untuk guru yang dilakukan oleh pemerintah menjadi kurang tepat sasaran karena adanya ketidaksesuaian dengan kondisi dan kebutuhan guru" (Kompas, edisi 21 November 2012).

Saat ini sebaran distribusi guru di tanah air masih kurang merata. Sebaran guru masih terpusat di kota-kota besar atau wilayah-wilayah tertentu. Bisa jadi di satu kabupaten, jumlah guru berlebih. Namun di kabupaten lain mengalami kekurangan guru. Di sisi lain, lanjut Syaiful Huda, proses penempatan dan mutasi guru kerap dilakukan dengan mengabaikan asas meritsystem. Mismanajemen distribusi guru ini berakibat pada kekurangan guru di satu wilayah sehingga satu guru harus merangkap bidang studi atau kelas agar proses belajar mengajar tetap bisa berlangsung, manajemen guru di Indonesia juga terkendala dengan rendahnya kompetensi guru. Kalau mutu guru kita rendah, pada akhirnya berdampak pada rendahnya kompetensi siswa, dan tentu saja ini mempengaruhi kemajuan bangsa secara keseluruhan ke depan.

Berdasarkan Hasil Uji Kompetensi Guru (UKG) bidang pedagogik dan profesional, ratarata kompetensi guru berkisar di angka 53,02. Capaian tersebut masih di bawah Standar Kompetensi Minimal (SKM) yang berada di angka 55. Data tersebut saya rasa belum banyak berubah sehingga kita masih punya PR besar dalam upaya mengembangkan kualitas guru di Indonesia. Salah satunya dengan mendorong para pendidik untuk mengikuti berbagai skema 
pelatihan baik dari Kemendikbud maupun institusi lainnya. Alasan peneliti mengambil tempat ini untuk dijadikan sebagai objek penelitian karena sekolah ini menggunakan kurikulum 2013 yang menjadi acuan pembelajaran dan penilaian. Dengan adanya penelitian ini, maka guru di tuntut untuk melakukan suatu pengembangan instrumen penilaian untuk menghadapi pendidikan di abad 21, dari kondisi tersebut peneliti tertarik dan berminat untuk melakukan suatu penelitian tentang kompetensi guru khususnya dalam menyusun instrumen penilaian pada mata pelajaran IPS di SDIT Al-Fityan Kecamatan Somba Opu Kabupaten Gowa.

\section{a) Hakikat seorang guru}

Guru adalah profesi yang sangat strategis dan mulia. Inti tugas guru adalah menyelamatkan masyarakat dari kebodohan, sifat, serta perilaku buruk yang menghancurkan masa depan mereka. Tugas tersebut merupakan tugas para Nabi, tetapi karena Nabi sudah tidak ada, tugas tersebut menjadi tugas guru. Jadi, guru adalah pewaris Nabi. Sebagai pewaris Nabi,guru harus memaknai tugasnya sebagai amanat Allah untuk mengabdi kepada sesamanya dan berusaha melengkapi dirinya dengan empat sifat utama para Nabi, yaitu sidiq (benar), amanah (dapat dipercaya), tabliq (mengajarkan semuanya sampai tuntas), dan fathanah (cerdas). Apabila keempat sifat tersebut ada pada guru, guru pasti dapat melaksanakan tugasnya secara profesional. (Suraji, 2008). Dalam Kamus Besar Bahasa Indonesia edisi kedua 1991, guru diartikan sebagai orang yang pekerjaannya (mata pencahariannya) mengajar. Dalam Undang-Undang Guru dan Dosen No. 14 Tahun 2005 Pasal 2, guru di katakan sebagai guru profesional yang mengandung arti bahwa pekerjaan guru hanya dapat dilakukan oleh seseorang yang mempunyai kualifikasi akademik, kompetensi, dan sertifikasi pendidik sesuai dengan persyaratan untuk setiap jenis dan jenjang pendidikan tertentu.

Mengutip pendapat Laurence \& Jonathan dalam bukunya This is Teaching (hal.10): "Teacher is professional person who conducts classes" (guru adalah seorang yang mempunyai kemampuan dalam menata dan mengelolah sekolah). Sementara menurut Jean \& Morris dalam Foundation of teaching, an Introduction to Modern Eductional (hlm. 14): "teacher are those persons who consciously direct the experiences and behavior of and individual so that education takes places”. Artinya, guru adalah mereka yang secara sadar mengarahkan pengalaman dan tingkah laku dari seorang individu sehingga dapat terjadi pendidikan (Uno, 2007).

Djohar (2006) mengatakan bila ingin mengangkat masalah profil guru pada dasarnya kita ingin mengajukan potret guru. Potret guru ini tentunya tidak akan tampak baik apabila kita gunakan objek guru masa kini dan masa lampau. Oleh karena itu, untuk menyajikan profil guru itu sebenarnya, dan untuk itu diperlukan pengalaman dan kreativitas kita untuk mewujudkan 
lukisan tersebut. Keutuhan lukisan tersebut dapat dikonstruksi dari ciri dasarnya, yaitu a) guru yang kompeten mengajar bidang studi yang di ajarkan; b) guru yang profesional dalam melaksanakan tugasnya; c) guru yang terampil dalam melaksanakan tugas kesehariannya. Apakah dengan tiga ciri itu telah mampu mewujudkan sosok profil seorang guru? Bila sudah, pertanyaannya adalah bagaimana menyiapkan profesi guru, dan bagaimana caranya membuat guru terampil melaksanakan tugasnya.

\section{b) Kompetensi Guru dalam konteks kebijakan}

Menurut UUGD No. 14/2005 Pasal 10 ayat 1 dan PP No. 19/2005 Pasal 28 ayat 3, guru wajib memiliki kompetensi yang meliputi kompetensi pedagogik, kepribadian, sosial dan profesional yang diperoleh melalui pendidikan profesi. Dalam kontes kebijakan tersebut, kompetensi profesional guru dapat diartikan sebagai kebulatan pengetahuan, keterampilan, dan sikap yang diwujudkan dalam bentuk perangkat tindakan cerdas dan penuh tangggung jawab yang dimiliki seseorang untuk memangku jabatan sebagai profesi.

\section{c) Pengertian Penilaian menurut Permendikbud Nomor 66 Tahun 2013 tentang Standar Penilaian Pendidikan}

Penilain dalam kurikulum 2013 mengacu pada Permendikbud Nomor 66 Tahun 2013 tentang Standar Penilaian Pendidikan. Standar penilaian bertujuan untuk menjamin: (1) perencanaan penilaian peserta didik sesuai dengan kompetensi yang akan dicapai dan berdasarkan prinsip-prinsip penilaian, (2) pelaksanaan penilaian peserta didik secara profesional, terbuka, edukatif, efektif, efisien, dan sesuai dengan konteks sosial budaya; dan (3) pelaporan hasil penilaian peserta didik secara objektif, akuntabel, dan informative. Standar penilaian pendidikan ini disusun sebagai acuan penilaian bagi pendidik, satuan pendidikan, dan pemerintah pada satuan pendidikan untuk jenjang pendidikan dasar dan menengah. Salah satu penekanan dalam kurikulum 2013 adalah penilaian autentik (authentic assessment). Lebih lanjut di jelaskan oleh Kunandar (2013), penilaian autentik adalah kegiatan menilai peserta didik yang menekankan pada apa yang seharusnya dinilai, baik proses maupun hasil dengan berbagai instrumen penilaian yang disesuaikan dengan tuntutan kompetensi yang ada di Standar Kompetensi (SK) atau Kompetensi Inti (KI) dan Kompetensi Dasar (KD).

\section{Metode Penelitian}

Jenis penelitian yang digunakan adalah penelitian kualitatif melalui pendekatan deskriptif. menurut Denzin dan Lincoln (1987) dalam Moleong (2017) menyatakan bahwa penelitian kualitatif adalah penelitian yang menggunakan latar alamiah, dengan maksud menafsirkan fenomena yang terjadi dan dilakukan dengan jalan melibatkan berbagai metode 
yang ada seperti menggabungkan metode wawancara, pengamatan, dan pemanfaatan dokumen dalam mengkaji suatu penelitian. Lokasi penelitian yang di pilih adalah SDIT Al-Fityan Kec. Somba Opu Kab. Gowa. Penentuan lokasi penelitian ini didasarkan atas pertimbangan 1) SDIT Al-fityan ini menggunakan Standar penilaian yang digunakan sesuai dengan kurikulum 2013; 2) Telah terakreditasi A; 3). Penelitian dilakukan selama dua bulan mulai September-November 2019. Penentuan informan dilakukan dengan teknik purposive sampling, pemilihan dilakukan secara sengaja berdasarkan kriteria yang telah ditentukan dan ditetapkan berdasarkan tujuan penelitian.

Teknik pengumpulan data melalui observasi, wawancara dan dokumentasi dengan menggunakan instrumen penelitian berupa pedoman observasi, pedoman wawancara dan dokumentasi berupa data-data kondisi fisik sekolah, letak sekolah, sarana penunjang pembelajaran, keadaan guru, dan pelatihan serta workshop yang sering diikuti. Analisis data menggunakan Model Interaktif Model Miles \& Huberman yaitu reduksi data, penyajian data dan penarikan kesimpulan. Pengecekan keabsahan data dengan teknik ketekunan pengamatan, triangulasi data, dan diskusi teman sejawat.

\section{Hasil dan Pembahasan}

Setelah diperoleh hasil observasi, wawancara dan dokumentasi maka hasil penelitian yang diperoleh sebagai berikut:

\section{Kompetensi guru dalam penyusunan instrumen penilaian di SDIT Al-Fityan Kecamatan Somba Opu Kabupaten Gowa.}

Pentingnya proses belajar-mengajar merupakan suatu proses saling berinteraksi antara guru dan siswa, secara sengaja atau tidak sengaja masing-masing pihak berada dalam suasana belajar. Dari proses belajar mengajar ini akan diperoleh suatu hasil, yang disebut hasil belajar. Di dalam proses belajar-mengajar, seorang guru dituntut untuk mempunyai kompetensi, baik dalam hal pengetahuan, kemampuan, sikap dan tata nilai serta sifat-sifat pribadi, agar proses itu dapat berlangsung dengan efektif dan efisien. Sebagaimana yang dipaparkan oleh kepala sekolah pada saat dilakukan wawancara. Berikut adalah kutipan hasil wawancara dengan Ibu Fatma selaku Kepala Sekolah bahwa:

"Pentingnya kompetensi pedagogik yang harus dimiliki oleh guru karena guru harus paham terhadap tanggung jawabnya sebagai tenaga pengajar misalnya melaksanakan perancangan, pelaksanaan pembelajaran, evaluasi, dan pengembangannya, dengan memahami semua aspek potensi peserta didik maka guru dapat menguasai teori dan strategi belajar serta pembelajarannya sehingga mampu merancang dan melakukan pengembangan akademik dan non akademik". Melalui pengamatan saya, rata-rata guru disini sudah memiliki kompetensi yang cukup baik untuk peningkatan 
kemampuan personal. Karena mereka sudah menguasai karakteristik peserta didik mulai dari aspek fisik, moral, spiritual, sosial, emosional dan intelektual. Mereka juga sudah menguasai teori belajar dan prinsip-prinsip pembelajaran yang mendidik. Bukan hanya itu,guru-guru disini juga sudah mengembangkan kurikulum yang terkait dengan mata pelajaran yang diampu. Selain itu, mereka juga memanfaatkan teknologi informasi dan komunikasi untuk kegiatan pembelajaran sehingga dalam penyelenggaraan penilaian dan evaluasi proses dan hasil belajar tidak akan menjadi suatu masalah di sekolah ini"

Hal serupa juga diungkapkan oleh Guru Kelas III dalam hal ini Ibu Mitha mengungkapkan bahwa:

"Saya sebagai seorang guru juga sangat senang jika guru yang mengajar di SD tidak hanya tahu cara mengajar, akan tetapi mengetahui cara menilai siswa dari hasil belajaranya dengan melakukan evaluasi melalui instrumen yang telah dibuat oleh guru. Dari hasil evaluasi tersebut maka seorang guru mengetahui berhasil tidaknya pembelajaran yang telah diajarkan. Dari cara penyusunan instrumen penilaian tersebut guru harus membuat RPP yang lengkap.

Paparan di atas diperjelas oleh Ibu Erni selaku Guru kelas IV mengatakan bahwa:

"Sebelum mengajar saya juga harus membuat RPP untuk panduan dalam pembelajaran di kelas, RPP yang saya susun harus saya bikin jauh-jauh hari sebelum KBM akan di mulai, dan yang menjadi acuan kami para guru untuk sekarang ini menggunakan K$13 "$

Tentang kompetensi pedagogik yang dikemukakan oleh wakil kurikulum dan para guru, dikuatkan dengan hasil observasi yang dilakukan oleh peneliti, adapun hasil observasi peneliti adalah sebagai berikut:

"10 September 2019, Guru-guru di SDIT pada saat ingin mengajar di kelas, jauh-jauh hari mereka telah mempersiapkan RPP untuk mempermudah proses pembelajaran, di dalam RPP yang telah mereka susun telah termuat instrumen penilaian yang akan dilakukan untuk mengukur kemampuan siswa dan yang menjadi acuan mereka untuk mengajar adalah kurikulum 2013. Betapa sulitnya membuat suatu rancangan dengan kurikulum tersebut, akan tetapi tanggung jawabnya sebagai seorang guru untuk tetap profesional dalam memenuhi tuntutan administratif yang harus lengkap. Kemampuan guru dalam pembuatan RPP merupakan bagian dari kemampuan pedagogik yang seharunya dimiliki oleh setiap guru dalam melaksanakan tanggung jawabnya"

Hal senada juga diutarakan oleh Bapak Dimas, selaku Waka Kesiswaan bahwa:

"Guru-guru sebelum masuk kelas harus mempunyai Silabus dan RPP yang telah disahkan oleh kepala sekolah melalui proses evaluasi dan supervisi. Silabus dan RPP dijadikan sebagai panduan untuk mengajar di dalam kelas. Tanpa adanya Silabus dan RPP maka guru tersebut tidak bisa melaksanakan pembelajaran di kelas" 
Masih dituturkan oleh Bapak Dimas, bahwa:

"Pembuatan RPP dilaksanakan sebelum awal tahun ajaran baru. Para guru dikumpulkan menjadi satu dan digabung dengan waka kurikulum dan waka-waka yang ada. Setelah itu di tentukan memakai kurikulum apa (K-13 dan kurikulum lokal). Setelah itu dialihkan kepada administrasi apa saja yang ada di RPP."

Pendapat diatas dibenarkan oleh Ibu Erma, selaku guru Bahasa Arab, bahwa :

"Memang benar bu, Setiap guru wajib membuat RPP dan pembuatan setiap RPP itu bervariasi sesuai dengan kreatifitas guru mengelola pembelajaran. Bahkan tidak hanya RPP saja, Silabus, Prota, Promes harus sudah siap"

Dari paparan data tersebut, Kompetensi Pedagogik guru di SDIT Al-Fityan Kec. Somba Opu Kab. Gowa bisa ditinjau melalui perancangan pembelajarannya. Seorang guru dalam penerapan pembelajaran harus menggunakan rancangan pembelajaran. Digunakan untuk titik acuan guru dalam pembelajaran di kelas. Tanpa adanya suatu rancangan pembelajaran seorang guru tidak bisa melaksanakan pembelajaran di kelas. Sejalan dengan visi dan misi yang menjadi acuan sekolah tersebut dalam hal ini SDIT AL-Fityan di Kabupaten Gowa. "Menjadi lembaga pendidikan yang terdepan dan unggul dalam pengajaran, pendidikan dan administrasi seIndonesia". Dalam mewujudkan visi tersebut tentunya stackholder memiliki perencanaan yang sangat sempurna untuk menjadikan sekolah tersebut sebagai sekolah unggulan yang bukan hanya unggul dalam bidang pengajaran, akan tetapi di bidang pendidikan yang berkarakter dan kelengkapan administrasi yang sudah bertaraf nasional yang bisa dijadikan acuan oleh sekolah lain.

Dari pemaparan kompetensi guru diatas, peneliti dapat jabarkan bahwa guru kelas rendah dan kelas tinggi di SDIT Al-Fityan tersebut sudah mempunyai kompetensi pedagogik yang cukup baik karena guru dituntut untuk menguasai karakteristik para peserta didik dalam berbagai aspek, diantaranya aspek fisik, moral, kultural, emosional dan intelektual selanjutnya guru harus menguasai teori belajar dan prinsip-prinsip pembelajaran yang mendidik, kemudian mengembangkan kurikulum yang terkait dengan bidang pengembangan yang diampu. Guru juga harus kreatif dan menyelenggarakan kegiatan pengembangan yang mendidik, memfasilitasi pengembangan potensi yang dimiliki.

\section{Faktor pendukung kompetensi guru dalam penyusunan instrumen penilaian di SDIT Al-Fityan kecamatan Somba Opu Kabupaten Gowa.}

Faktor yang dapat mendukung guru dalam mewujudkan kinerjanya sebagai guru yang profesional khususnya dalam pembuatan instrumen penilaian bisa lahir melalui dirinya sendiri maupun dari luar dirinya. Seorang pendidik hendaknya memiliki semangat yang kuat dalam 
menjalankan tugasnya, sehingga ia dapat bertanggung jawab dengan baik dalam mendidik, mengarahkan, memotivasi para peserta didik. semangat dalam dirinya sangat berdampak pada cara seorang pendidik mengajar dan memenuhi tuntutan administrasi sekolah yang harus dikerjakan.

Selain itu seorang pendidik harus mempunyai latar pendidikan yang cukup tinggi untuk peningkatan kompetensinya, kesesuaian antara latar belakang pendidikan yang ditempuh guru dengan bidang tugasnya akan mempengaruhi kompetensi guru itu sendiri. Guru dengan latar belakang pendidikan keguruan akan lebih berkompeten dalam menjalankan tugas profesinya sebagai guru, karena telah memiliki bekal teori sebagai pendukung pengabdiannya, selain itu juga lebih mudah menyesuaikan diri dengan lingkungan sekolah. Dari hasil observasi yang telah dilakukan oleh peneliti maka sarana dan prasarana juga sangat mendukung peningkatan kompetensi guru untuk mewujudkan kinerja profesional karena proses pelaksanaan kegiatan pembelajaran akan menjadi lebih efektif dan efisien ketika hal tersebut dapat terpenuhi dengan baik dan memadai.

Sebagaimana yang disampaikan oleh guru kelas V dalam hal ini ibu Vina, mengatakan bahwa:

"Sebenarnya, faktor pendukung kompetensi guru itu sangatlah banyak akan tetapi hal yang paling mendasari kompetensi tersebut adalah diri kita sendiri, tanpa adanya dorongan dalam diri untuk melakukan suatu perubahan maka hal itu akan mustahil kita lakukan. Dengan niat yang ikhlas dan tulus untuk sebuah perubahan ke arah yang lebih baik maka kita tidak sepatutnya hanya tinggal berpangku tangan, untuk itu kita harus bergerak dan berproses demi tercapainya tujuan pendidikan yang berkemajuan. Apabila saya akan mengikuti sebuah pelatihan maka saya difasilitasi oleh stack holder sekolah untuk kegiatan tersebut, misalnya memakai laptop dalam kegiatan, memakai LCD untuk pengembangan personal dan dipinjamkan mobil atau motor untuk mengikuti kegiatan..he.he.he

Senada dengan apa yang disampaikan waka kesiswaan dan guru kelas V, juga dikuatkan oleh Wakasek Yayasan. Ia menyampaikan bahwa:

"Di sekolah kami ini, sangatlah mengapresiasi guru-guru yang ingin meningkatkan kompetensinya karena kami memfasilitasi apa yang mereka butuhkan. Maka dari itu, pentingnya peningkatan kompetensi guru sebagai ujung tombak pendidikan. Salah satu upaya yang dapat dilakukan adalah mengikuti kegiatan pengembangan diri. melalui pelatihan kompetensi guru.

Dari pernyataan wakasek dan guru diatas dapat diketahui bahwa upaya yang dilakukan oleh Yayasan Al-Fityan yaitu pengembangan diri melalui kegiatan KKG untuk guru SD sebenarnya sangat efektif. Dalam kegiatan ini guru satu dengan lainnya bisa saling bertukar pengalaman dan menjadi wahana bersama dalam upaya pemecahan masalah keseharian. 


\section{Faktor penghambat kompetensi guru dalam penyusunan instrumen penilaian di SDIT Al-Fityan kecamatan Somba Opu Kabupaten Gowa}

Faktor penghambat guru dalam mewujudkan kinerjanya berasal dari guru itu sendiri seperti kurangnya rasa motivasi dalam diri sendiri untuk memenuhi tuntutan administratif sekolah. Kondisi sosial yang terjadi dilapangan, bahwa pemenuhan kebutuhan guru terhadap kompetensinya berasal dari dirinya sendiri untuk selalu memunculkan motivasi agar kegiatan pada saat perencanaan smpai evaluasi pembelajaran dapat berjalan sesuai dengan mestinya, motivasi yang tidak ada menyebabkan guru menjadi kurang bersemangat dalam mengajar dan melengkapi RPP dengan instrumen penilaian yang valid sehingga kurang efektif dalam proses mengajar dan mengevaluasi. Berikut pernyataan dari Ibu DL guru kelas tentang faktor penghambat kompetensi guru dalam penyusunan instrumen penilaian:

"Penilaian pada Kurikulum 2013 relatif kompleks dan rumit sehingga guru terkadang malas untuk melakukan penilaian yang efisien dan efektif. Guru harus merancang dan mengembangkan instrumen penilaian berdasarkan pada kompetensi yang akan dicapai. Guru dituntut untuk dapat mengembangkan instrumen penilaian yang dapat mengukur kemampuan siswa sesuai dengan tujuan pembelajaran. Terlalu banyak tuntutan administratif guru yang harus dilengkapi sehingga saya biasanya malas untuk penyusunan instrumen penilaian sendiri, saya hanya mengcopy paste di internet supaya tidak terlalu lama menyita waktu saya untuk membuat suatu instrumen penilaian.

Setelah peneliti melakukan wawancara dengan ibu ER, hal di atas dibenarkan oleh Ibu AP, yang menyatakan bahwa:

"Memang benar bu, pembuatan instrumen penilaian untuk K-13 sangatlah ribet karena banyaknya penilaian yang harus kita gunakan dan cocokkan untuk setiap tema yang harus di ajarkan, sebelum penyusunan instrumen penilaian, kita harus tau dulu apakah penilaian yang kita gunakan valid atau tidak, sudah sesuai dengan aspek penilaian afektif, psikomotorik, dan kognitif.

Dengan adanya pergantian kurikulum yang dipakai di sekolah tersebut, seorang guru harus siap untuk menerima semua perubahan yang akan terjadi. Para guru harus sudah mempunyai rencana untuk menindak lanjuti terkait perubahan kurikulum. Seperti halnya pernyataan yang dikemukakan oleh Ibu MN bahwa:

"Saya juga waktu diberlakukan kurikulum 2013, ribet sekali saya rasa bikin RPP karena tematik yang digunakan itu di gabung semua mata pelajaran jadi tema. Inimi saya biasanya sulit sekali saya pelajari bikin RPP. Coba bisa pake KTSP saja deh yang kaya dulu karena tidak rempong jie".

Terlaksananya pembelajaran yang baik dan efektif menjadi tujuan pembelajaran oleh guru. Pelaksanaan penilaian pada kurikulum 2013 harus mencapai tiga ranah yaitu kognitif, afektif dan psikomotorik sesuai dengan tujuan yang hendak diukur. Penekanan penilaian 
menyeluruh terhadap tiga aspek memberikan perubahan besar dibanding kurikulum sebelumnya. Seorang guru tidak hanya dituntut dengan pembuatan instrumen penilaian yang valid akan tetapi kesesuaian antara tiga ranah yang akan kita nilai harus sesuai dengan instrumen penilaian yang disusun oleh guru. Seperti halnya yang dikatakan oleh Ibu SR bahwa:

"ketepatan pemilihan metode penilaian akan sangat berpengaruh terhadap objektivitas dan validitas hasil penilaian yang ujungnya adalah informasi objektivitas dan valid atas kualitas pendidikan, pada kurikulum 2013 kita harus mengkaji dulu silabus sebagai acuan perencanaan penilaian, pembuatan kisi-kisi instrumen dan penetapan kriteria penilaian. Banyak sekali yang harus kita pikirkan untuk penyusunan instrumen penilaian tersebut, belumpi lagi kalau dideskripsikanmi pencapaian kompetensi dan deskripsi sikap yang harus dibuat oleh guru.

Dari hasil wawancara peneliti dengan informan pada tanggal 15 Oktober 2019, perpindahan kurikulum ini menyebabkan seorang guru harus lebih meningkatkan kemampuannya lagi dalam penyusunan instrumen penilaian. Dari pernyataan diatas dapat disimpulkan bahwa kurikulum 2013 menjadi faktor pemicu yang dapat menghambat kompetensi guru untuk membuat instrumen penilaian khususnya pada kurikulum 2013.

\section{Kesimpulan dan Saran}

Berdasarkan hasil analisis data, maka dapat disimpulkan bahwa guru kelas di SDIT Alfityan Kec. Somba Opu Kab. Gowa sudah memiliki kompetensi pedagogik yang baik dalam penyusunan instrumen penilaian, hal ini ditandai dengan adanya telaah dokumen yang dilakukan oleh peneliti pada silabus dan RPP yang digunakan oleh guru yang mengajar di kelas rendah dan kelas tinggi. Selain itu faktor pendukung kompetensi guru di SDIT Al-Fityan setelah dilakukan penelitian yaitu;

a) Tingkat pendidikan yang tinggi akan menjadi pembeda dari pribadi seorang guru dalam menjalankan tugasnya.

b) Keikutsertaan dalam berbagai pelatihan dan kegiatan ilmiah

c) Masa kerja dan pengalaman kerja

d) Tingkat kesejahteraan

e) Kesadaran kewajiban dan panggilan hati nurani.

f) Ketersediaan sarana dan prasarana

g) Kepemimpinan kepala sekolah

h) kegiatan pembinaan yang dilakukan.

Sedangkan faktor penghambat dari sebagian guru tentang kompetensi guru dalam menyusun instrumen penilaian yang didapatkan oleh peneliti setelah melakukan penelitian 
yaitu berasal dari diri guru itu sendiri karena kurangnya pemahaman kurikulum 2013 dan baginya sangat rumit untuk melakukan suatu penilaian.

Penelitian dilakukan hanya pada kompetensi guru pada penyusunan instrumen penilaian, disarankan untuk penelitian selajutnya agar melakukan penelitian terkait kompetensi guru tentang pengembangan instrumen penilaian IPS pada ranah afektif, kognitif dan psikomotorik.

\section{DAFTAR PUSTAKA}

Alwasilah dan Sudrajat, A. (1996). Glossary of educational Assessment Term. Jakarta : Ministry of Education and Culture.

Arifin, Z. (2009). Evaluasi Pembelajaran. Bandung: PT Remaja Rosdakarya.

Arikunto, S., \& Jabar, C. S. A. (2004). Evaluasi program pendidikan pedoman teoritis praktis bagi praktisi Pendidikan. Jakarta: Bumi Aksara.

Asrori, I., Thohir, M., \& Ainin, M. (2012). Evaluasi Pembelajaran Bahasa Arab. Malang: Misykat.

Convelo, G. Cevilla. (1993). Pengantar Metode Penelitian, Jakarta: Universitas Indonesia.

Depdiknas. (2003). Kurikulum 2004 Pedoman Penilaian Kelas. Jakarta: Departemen Pendidikan Nasional.

Depdiknas. (2005). Depdiknas. 2005. Peraturan Pemerintah Republik Indonesia No. 19 Tahun 2005 tentang standar Nasional Pendidikan. Jakarta: Depdiknas.

Depdiknas. (2007). Peraturan Menteri pendidikan nasional republik Indonesia nomor 16 Tahun 2007 tentang standar kualifikasi akademik dan kompetensi guru. Jakarta: Depdiknas.

Djohar, M. S. (2006). Guru, Pendidikan, dan Pembinaan: Penerapannya dalam Pendidikan dan UU Guru. Yogyakarta: Graha Indah.

Hamalik, O. (2001). Kurikulum dan Pembelajaran (Jakarta: Bumi Aksara, 200I). I30.

Jarolimek, J. (1964). Social Studies in Elementary Education Second Edition 2nd ed. The Macmillan Company.

Kumano, Y. (2001). Authentic Assessment and Portfolio Assessment-Its Theory and Practice. Japan: Shizuoka University.

Kunandar, G. P. I. K. T. (2007). Satuan Pendidikan (KTSP) dan Persiapan Menghadapi Sertifikasi Guru. Jakarta: PT Raja Grafindo Persada.

Kunandar, K. (2013). Penilaian autentik (Penilaian hasil belajar peserta didik berdasarkan Kurikulum 2013). Jakarta: Rajawali Pers. 
Mardalis. (1999). Metode Penelitian Suatu Pendekatan Proposal. Bumi Aksara: Jakarta.

Chatib, M. (2009). Sekolahnya manusia: sekolah berbasis multiple intelligences di Indonesia. Kaifa.

Moleong, L. J. (2013). Metode penelitian kualitatif (Revisi). Bandung: PT. Remaja Rosdakarya.

Moleon, L. J. (2017). Metode Penelitian Kualitatif. Edisi Revisi. PT. Remaja Rosdakarya: Bandung.

Sukmadinata, N. S. (2010). Metode penelitian pendidikan bandung. Remaja rosdakarya.

Surapranata, S., \& Hatta, M. (2004). Penilaian portofolio implementasi kurikulum 2004. Bandung: PT. Remaja Rosdakarya.

Suprihatiningrum, J. (2013). Guru profesional: pedoman kinerja, kualifikasi \& kompetensi guru. Ar-Ruzz Media.

Surya, M. (2005). Perlindungan Profesi Guru: Kode Etik Dan Undang-Undang Guru. Makalah). Bandung: UPI Bandung.

Syah, M., \& Belajar, P. (2004). Psikologi Pendidikan dengan Pendekatan Baru, Cet. IX. Bandung: PT. Remaja Rosdakarya.

Tayibnapis, F. Y. (2000). Evaluasi program. Jakarta: Rineka Cipta, 23-36.

Uno, Hamzah B. 2007. Profesi Kependidikan: Problema, Solusi, dan Feformasi Pendidikan di Indonesia. Edisi 1. Cet.1. Jakarta: Bumi Aksara.

Widaningsih, Dedeh. (2011). Perencanaan Pembelajaran. Tasikmalaya: Rizqi Press.

Yusuf, A. M. (2017). Asesmen dan evaluasi pendidikan. Prenada Media.

Zainul, A., \& Nasution, N. (2001). Penilaian hasil belajar. PAU untuk peningkatan dan Pengembangan Aktivitas Instruksional Ditjen Dikti, DepDiknas, Jakarta 